\section{Klisze i prześwietlenia. Braki i naddatki polskiej pamięci}

Justyna Tabaszewska

TEKSTY DRUGIE 2016, NR 6, S. 375-386

DOI: $10.18318 /$ td.2016.6.22
Badania zostały sfinansowane ze środków Narodowego Centrum Nauki przyznanych w ramach finansowania stażu po uzyskaniu stopnia naukowego doktora na podstawie decyzji numer DEC-2014/12/S/HS2/0007
Gdy spoglądamy na polską pamięć z perspektywy referatów wygłoszonych podczas konferencji „Polska pamięć. Ciągłość i przemiany; diagnoza i rokowania”, które stały się podstawą zamieszczonych w tym czasopiśmie artykułów, łatwo dostrzec dwa główne problemy w funkcjonowaniu polskiej pamięci, na jakie zwracają uwagę badacze. Pierwszym z nich są niewątpliwe luki w pamięci, punkty lub całe przestrzenie, których pamiętać nie chcemy, które z pamięci są wypychane lub też na dobrą sprawę nigdy do niej nie trafiły'. Drugim - jak łatwo można się domyślić - nadmierna tendencja do pamiętania innych wydarzeń, bez względu na upływ czasu, a nawet wbrew niemu, do

1 Do tej kategorii należy bez wątpienia spora część pamięci dotyczącej Holokaustu, a zwłaszcza tych jego aspektów, które wskazują albo na przyzwolenie na Zagładę i udział części społeczeństwa w poszczególnych aktach ludobójstwa, albo też brak jakiejkolwiek reakcji na nie (na co jasno wskazują referaty Doroty Głowackiej, Przemysława Czaplińskiego, Jacka Leociaka i Marka Zaleskiego). Pomijana jest jednak nie tylko pamięć wydarzeń, które mogą być źródłem winy lub wstydu, lecz także wszystkie te formy pamięci, które nie wpisują się w bardzo uproszczony schemat pamięci bezpiecznej dla tworzenia tożsamości narodowej.

\section{Justyna}

Tabaszewska

- doktor nauk

humanistycznych,

autorka książek/edna przyroda czy przyrody alternatywne? O pojmowaniu i obrazach przyrody w polskiej poezji i Poetyki pamięci.Współczesna poezja wobec tradycji i pamięci oraz artykułów publikowanych m.in. w „Tekstach Drugich” i „Przeglądzie Kulturoznawczym". Aktualnie pracuje w Instytucie Badań Literackich nad projektem „Afektywne poetyki pamięci. Polska literatura i kultura wobec przełomu roku 1989". Kontakt: justyna.tabaszewska@uj.edu.pl 
powtarzania i multiplikowania określonych form pamięci w prawie niezmienionej, a możliwie prostej formie².

Niepamiętanie i rozpamiętywanie stanowią dwa aspekty tego samego procesu; procesu ujednolicania pamięci, konstruowania jej w taki sposób, by była wygodnym narzędziem w budowie określonej tożsamości zbiorowej. Dynamika relacji między tymi dwoma zjawiskami przypomina za każdym razem ruch wahadła zegara, wychylającego się raz w jedną, raz w drugą stronę. Zauważane i komentowane przez badaczy problemy oraz zjawiska mieszczą się dość ściśle w owym bardzo prostym schemacie: albo pamięć zbiorowa odmawia współpracy, gdy w grę wchodzi pamiętanie zdarzeń zbyt skomplikowanych, obciążających czy choćby niewygodnych (od Holokaustu zaczynając, na skomplikowanej pamięci PRL-u i czasów transformacji politycznej kończąc), albo reprodukuje kolejne pamięciowe klisze, gdy dotyka wydarzeń o potencjale tożsamościotwórczym dla określonej wspólnoty.

Zjawisko to - szczególnie widoczne w odniesieniu do II wojny światowej - można moim zdaniem interpretować jako rodzaj specyficznego zapętlenia pamięci. Próby ujednolicenia pamięci, nadania przeszłości spójnej formy, choć powtarzane regularnie, nie wpływają wcale na jej uspójnienie. Przeciwnie, w momencie, gdy nasze wspomnienia o wydarzeniach sprzed siedemdziesięciu lat powinny - jak sugerował w swoich badaniach Jan Assmann, stopniowo przechodzić z pola pamięci komunikacyjnej do pola pamięci kulturowej ${ }^{3}$, coś się psuje. Pamięć o II wojnie światowej, tak jak i pamięć o kolejnych traumatycznych doświadczeniach z XX wieku, okazuje się wciąż otwarta, podatna na zmiany oraz manipulacje, gotowa na przekształcenia wynikające zarówno z przemilczeń, jak i powtórzeń.

Polska pamięć, zwłaszcza ta dotycząca traumatycznych i wciąż afektywnych wydarzeń XX wieku, jest więc nie tyle dynamiczna, co rozchwiana. Ciągłe powroty do wciąż nieprzepracowanych zdarzeń nie przyczyniają się jednak do zamknięcia przeszłości. Choć wydaje się, że były początkowo podejmowane - aczkolwiek to zawsze złudna motywacja - w imię odkłamania przeszłości, opowiedzenia tego, co i jak się wydarzyło naprawdę, to jednak dość

2 Tego typu pamięciowe klisze łatwo zauważyć w przypadku narracji o ll wojnie światowej, która wciąż - jeśli by za punkt odniesienia wziąć przekaz medialny lub nawet podręczniki do historii - opiera się na bardzo prostym schemacie przedstawiania Polski jako głównej ofiary tego globalnego przecież w swej skali wydarzenia. Przekaz o innym niż lokalny (a już szczególnie innym niż europejski) wymiar II wojny światowej jest wciąż bardzo ograniczony.

3 J. Assmann Pamięć kulturowa. Pismo, zapamiętywanie i polityczna tożsamość w cywilizacjach starożytnych, przeł. A. Kryczyńska-Pham, Wydawnictwa UW, Warszawa 2008. 
szybko okazywało się, że nie chodzi wcale o powrót do przemilczanych czy niewygodnych wydarzeń, lecz o próbę stworzenia innej, ale możliwie spójnej wersji przeszłości. A to możliwe jest tylko za sprawą uporczywych przemilczeń i kompulsywnych powtórzeń.

Choć zjawisko, o którym tu wspominam, bardzo dobrze opisują na konkretnych przykładach uczestnicy konferencji, warto moim zdaniem poświęcić mu również nieco uwagi jako specyficznemu procesowi, regulującemu obieg polskiej pamięci i zastanowić się, co sprawia, że mimo upływu lat tak trudno o tworzenie pamięci, którą można by określić - używając przydatnej tu terminologii Aleidy Assmann ${ }^{4}$ oraz Michaela Rothberga ${ }^{5}$ - dialogicznej lub wielokierunkowej.

\section{II}

Pomijanie w pamięci określonych wydarzeń i przywiązywanie nadmiernej wagi do innych albo - w łagodniejszej formie - preferowanie określonych wizji przeszłości nie jest niczym nowym w polskiej kulturze, nie wyróżnia jej także wśród innych. Początkowe rozchwianie zbiorowej pamięci po trudnym i traumatyzującym wydarzeniu nie wydaje się szczególnie zaskakujące. Z podobnymi wyzwaniami mierzyła się - nie szukając przykładów daleko niemiecka pamięć kulturowa po II wojnie światowej ${ }^{6}$, nie są one obce również pamięciom zbiorowym tych społeczności, które dopiero teraz przepracowują swoją kolonialną przeszłość. Tym jednak, co odróżnia polską pamięć, jest jej skrajna niestabilność, która wraz z upływem czasu nie tylko nie mija, ale wręcz się pogłębia.

4 Por. A. Assmann Podzielona Pamięć Europy. Koncepcja pamięci dialogicznej, w: Dialog kultur pamięci w regionie ULB, red. A. Nikžentaitis, M. Kopczyński, przeł. E. Grotek, Muzeum Historii Polski, Warszawa 2014.

5 Por. M. Rothberg, Multidirectional Memory: Remembering the Holocaust in the Age of Decolonization, Stanford University Press, Stanford 2009. Przekład polski: M. Rothberg Pamięć wielokierunkowa. Pamiętanie Zagłady w epoce dekolonizacji, przeł. K. Bojarska, Wydawnictwo IBL PAN, Warszawa 2016. O koncepcji pamięci wielokierunkowej Michaela Rothberga bardzo przekonująco pisała również Katarzyna Bojarska w tekście Polska pamięć wielogłosowa i wielokierunkowa? (Kto nie pamięta z nami, ten pamięta przeciwko nam) w niniejszym numerze "Tekstów Drugich".

6 Wnikliwie pisała o tym m.in. Aleida Assmann. Por. A. Assmann Re-framing Memory. Between Individual and Collective Forms of Constructing the Past, w: Performing the Past Memory, History, and Identity in Modern Europe, ed. by K. Tilmans, F. van Vree, J. Winter, Amsterdam University Press, Amsterdam 2010. 
Przyczyny owej niestabilności tkwią moim zdaniem właśnie w owym chronicznym zapętleniu pamięci, które sprawia, że niektóre wydarzenia z dość już dawnej przeszłości funkcjonują wciąż jako świeże, otwarte, teraźniejsze. Druga wojna światowa jest - odwołując się do koncepcji Lauren Berlant $^{7}$ - takim właśnie wydarzeniem, które nieprzepracowane do końca wciąż zmienia współczesną strukturę afektów. Jako takie, zanim zdążyło zostać przeżyte do końca, zniknęło z pola publicznej dyskusji, zagłuszone, choć przecież niezatarte, przez kolejne wydarzenie - zmianę ustroju politycznego. Po 1989 roku wcześniej stłumiona, lecz w dalszym ciągu afektywna w swym charakterze pamięć o II wojnie światowej stała się dla polskiej tożsamości wyzwaniem.

Specyfikę tego wyzwania dobrze opisuje dialektyka wstydu i dumy, sprawnie wykorzystywana w różnych dyskursach pamięciowych. Jej działanie - już w przypadku polskiej kultury - w wyjątkowo interesujący sposób interpretuje Przemysław Czapliński w artykule o wymownym tytule Wojna wstydów. Warto moim zdaniem zacytować jego fragment:

kultura polska uczestniczy dziś w wojnie dwóch wstydów prawomocnych. Pierwszy, pokawałkowany, wewnętrznie niespójny i skonfliktowany, wyrasta na podłożu etycznej troski o prawa mniejszości; drugi, wąski i agresywnie nastawiony do wszelkich różnic, odwołuje się do etyki praw większościowych; pierwszy nie potrafił zaspokoić masowej potrzeby szacunku, drugi szafuje uznaniem wyłącznie dla „swoich”. Pierwszy proponował chrześcijańską zasadę „Bądź dumny, jeśli potrafisz się wstydzić!”, drugi forsuje plemienną maksymę „Wstydź się, jeśli nie potrafisz być dumny!”.

Dwa rodzaje wstydu, o których pisze Czapliński, odpowiadają za dwie skrajnie różne postawy regulujące stosunek jednostek i społeczeństw do przeszłości. Pierwsza, nakazująca branie odpowiedzialności także za wydarzenia, które nie budują pozytywnego obrazu danej społeczności, traktuje pamięć nie jako prosty rezerwuar zdarzeń i postaw, które można ze współczesnej perspektywy pozytywnie oceniać i z którymi można się identyfikować, lecz jako zadanie oraz wyzwanie wymagające pracy. Druga zaś nakazuje przechowywanie w pamięci głównie - jeśli nie wyłącznie - tego, z czego

7 L. Berlant Intuitionists: History and the Affective Event, w: American Literary History, Oxford University Press, Oxford 2008.

8 P. Czapliński Wojna wstydów „"Teksty Drugie” 2016 nr 4, s. 44. 
można być dumnym, co może służyć jako budulec pozytywnie wartościowanej tożsamości.

Nietrudno zauważyć, że pierwsza maksyma, o której wspomina Czapliński, nie jest reprezentatywna dla polskiego stosunku do pamięci. Zauważa to również Andrzej Leder, wskazując, że:

Zdolność do takiego wstydu, wstydu za zbrodnie, których autorami byli nasi poprzednicy - nosiciele tej samej tradycji, którzy jednak zaniedbali obowiązek rozliczenia się - stała się miarą nowego rodzaju dumy. Dumy, która z pozycji przyszłości, wspólnej przyszłości wolnych i równych sobie ludzi, sądziła straszną przeszłość, która ukrywała się w teraźniejszości.9

Analizując wzajemne relacje wstydu i dumy oraz role, jakie odgrywają one we współczesnych społeczeństwa, Leder uznaje, że ich funkcjonowanie jest zasadniczo odmienne w słabych i silnych społeczeństwach. Duma z umiejętności odczuwania wstydu charakteryzuje te społeczeństwa, które były niegdyś wystarczająco silne, by przymusem i przemocą narzucać swoją wolę innym społeczeństwom, a teraz są wystarczająco świadome i zdyscyplinowane, by - także dla ochrony swojej własnej tożsamości oraz związanej z nią sprawczości - wziąć odpowiedzialność za przeszłe winy:

Proces rozliczania win ojców najgwałtowniej przebiegał - i przebiega - w społeczeństwach, które niedawno, w XIX wieku, historycznie były wystarczająco silne, by móc okrutnie krzywdzić całe społeczności, narody, cywilizacje [...] Musiały wreszcie mieć szczególny rodzaj suwerenności, który nakazuje mówić: to my! Brać odpowiedzialność, również za sprawy trudne i złe. Doświadczenie sprawczości tych wspólnot uniemożliwiało uspokajające słowa: to inni. Typowe dla społeczeństw słabych. ${ }^{10}$

W przeciwieństwie do silnych społeczeństw, które budują swoje poczucie dumy na akceptacji wstydu, słabe społeczeństwa - jak wskazuje Leder - chcą dumy bez wstydu, a więc w gruncie rzeczy dumy z uznania ich braku sprawczości. To zaś jeszcze bardziej pogłębia różnice między słabymi i silnymi społeczeństwami, między sprawczymi i gotowymi do przyjęcia

9 A. Leder Pole symboliczne. Przemieszczanie, niewczesność. Humanistka jako wybór między pamięciq a nadzieją, "Teksty Drugie" 2016 nr 4, s. 247.

10 Tamże, s. 248. 
odpowiedzialności za swoje czyny oraz biernymi, a unikającymi jakichkolwiek konsekwencji swoich czynów.

Dialektyka dumy i wstydu do pewnego stopnia dobrze opisuje wspominane przeze mnie na początku zjawisko niepamiętania i rozpamiętywania przeszłości. To, że społeczeństwo polskie o wiele chętniej wybiera dumę bez wstydu niż dumę, która z umiejętności akceptowania winy czerpie swoją siłę, jest obecnie wyjątkowo wyraźnie widoczne. Warto jednak nieco poszerzyć lub nawet przeformułować pytanie o niechęć wobec dumy ze wstydu, o jej tak silne wypieranie. Wiąże się ona moim zdaniem nie tylko i nie tyle z chęcią przerzucenia winy na innych, lecz przede wszystkim z coraz większym problemem z określeniem własnej tożsamości, ze wskazaniem, kim właściwie jesteśmy 'my'?

\section{III}

Podział na społeczeństwa słabe i silne, tak jak przedstawiał go Andrzej Leder, opiera się nie tylko na umiejętności - bądź jej braku - czerpania dumy ze wstydu. Opiera się on również - co badacz wyraźnie podkreśla - na określonym operowaniu prostym rozgraniczeniem, na my i oni, my i inni. Umiejętność przyznania się do winy i uznania wstydu wymaga przecież, jak pisze Leder, jasnego postawienia sprawy, powiedzenia: to my. Co jednak dzieje się w przypadku, w którym to najprostsze, najbardziej podstawowe rozgraniczenie dla budowania tożsamości zbiorowej, narodowej i społecznej, wcale takie proste nie jest? Co jeśli cały problem polega na tym, że trudno odnaleźć punkt, z którego wiadomo, kto jest po jakiej stronie? Przeszłość mocarstw kolonialnych jest pod tym względem prostsza do pojęcia, trudno pomylić kolonizatora z kolonizowanym, ciężko również odmawiać odpowiedzialności za wywołanie II wojny światowej państwu, które wyraźnie do niej dążyło. Pozycja mocnych społeczeństw, tych, które mają za sobą wielowiekową historię dominacji i ekspansji, jest pod tym względem o wiele prostsza niż społeczeństw określanych przez Ledera jako słabe. Przeszłość, za którą można - lub trzeba - wziąć odpowiedzialność, za którą nawet wypada się wstydzić, może być mocniejszą podstawą tożsamości niż przeszłość, którą trzeba wyjaśniać i opowiadać na nowo, ponieważ nie sposób przypisać sobie pełnej sprawczości ani - jeśli nie chce się owej przeszłości zakłamywać - całkiem pozbawić się odpowiedzialności. Przeszłość słabych społeczeństw to przecież nie tylko doświadczanie przemocy, lecz także - na mniejszą lub większą skalę - jej wyrządzanie, to najczęściej bycie raz po stronie słabych, raz silnych. 
Pamięć słabych społeczeństw jest więc o wiele bardziej skomplikowana i zdaje się zdecydowanie gorzej wybaczać zapomnienia i przemilczenia niż pamięć silnych. Jest ona też o wiele bardziej tkliwa niż te pamięci zbiorowe, które mogą schować się za figurą wielkiego mocarstwa: odpowiedzialność polityczna i etyczna państw za określone działania jest czymś zgoła innym niż wstyd odczuwany przez społeczeństwo za czyny swoich członków11.

Jeśli więc uznamy - za Lederem - że polskie społeczeństwo jest słabe, łatwo będzie zauważyć, iż szczególnie zapalne punkty polskiej pamięci, miejsca niepamiętania lub rozpamiętywania dotyczą w głównej mierze tych momentów z przeszłości, w których funkcjonowanie polskiego państwa jest w mniejszym lub większym stopniu zaburzone. A to oznacza, że obciążają one właśnie społeczeństwo, że nie da się ich złożyć na karb funkcjonowania jakiegoś mniej lub bardziej abstrakcyjnego bytu państwowego.

Wstyd silnych społeczeństw, z jasno zarysowaną odpowiedzialnością państwową, a nie tylko społeczną, za określone czyny, jest - jak zauważa Sara Ahmed - łatwiejszy. Oddziela poszczególne jednostki od narodu i państwa, pozwala na odzyskanie dumy niejednokrotnie tylko za pomocą dość powierzchownego aktu, wcale nie nakierowanego na wyrównanie szkód ${ }^{12}$.

Sytuację tę dobrze ilustrują choćby meandry niemieckiej pamięci zbiorowej dotyczącej II wojny światowej. Uznanie odpowiedzialności Niemiec jako określonego tworu państwowego za wybuch II wojny światowej dokonało się stosunkowo łatwo. Jednak przekucie tej odpowiedzialności w uznanie zbiorowej winy społeczeństwa niemieckiego za dopuszczenie do tego wydarzenia oraz czynne uczestniczenie lub popieranie nazistowskich działań przebiegało już znacząco wolniej. W pewnym momencie doszło więc do wymownego podziału odpowiedzialności, w którym uznawano winę państwa jako abstrakcyjnego, politycznego bytu, ale już nie społeczeństwa jako zbioru konkretnych jednostek, a jego przełamanie nie było proste. Por. H. Welzer, S. Moller, K. Tsschuggnall "Dziadek nie był nazista". Narodowy socjalizm i Holokaust w pamięci rodzinnej oraz J. Rusen Pamięć o Holokauście a tożsamość niemiecka, w: Pamięć zbiorowa i kulturowa. Współczesna perspektywa niemiecka, Universitas, Kraków 2009.

Por. S. Ahmed Wstyd w obliczu innych, "Teksty Drugie” 2016 nr 4, s. 211: „[Sposoby wyrażania] narodowego wstydu [...] były problematyczne, ponieważ w ramach wypowiedzi próbowały zakończyć działanie, uznając, że wyrażenie wstydu wystarczy, by przywrócić narodową dumę. Jako takie, nie funkcjonowały jako adres zwrotny. Uniemożliwiały wysłuchanie świadectwa innego, ponieważ odwracały się w stronę «ideału» narodu. Jednak możliwe pozostaje wyrażenie wstydu w obliczu innych bez domykania samego aktu; wstydu, który odmawia owej transformacji w dumę, który pojawia się nie tylko w obliczu innych, lecz również dla innych". Badaczka wskazuje, że nie każdy rodzaj publicznego wstydu jest otwarciem na dialog z tymi, którym wyrządzono krzywdę. Przeciwnie, wstyd służy czasem jako rodzaj publicznego zamknięcia dyskusji na określony temat. 
Tymczasem odpowiedzialność społeczeństw, które nie mogą się ukryć za figurą państwa lub rządu, jest o wiele bardziej osobista, zdecydowanie bardziej obciążająca i dotkliwa. Dobrym przykładem jest pod tym względem sytuacja Polski podczas II wojny światowej. Od października 1939 roku polskie społeczeństwo pozostaje pod całkowitym wpływem obcego rządu i jest zmuszone poddać się określonemu porządkowi politycznemu i prawnemu. Działalność rządu na uchodźstwie zasadniczo nie zmienia tej sytuacji: choć rząd ten mógł w minimalnym stopniu reprezentować interesy abstrakcyjnego bytu państwowego na arenie międzynarodowej, nie miał realnego wpływu na to, co dzieje się w granicach administracyjnych przedwojennego państwa polskiego. Faktu tego nie zmienia nawet funkcjonowanie w kraju formacji wojskowych czy Państwa Podziemnego - ich istnienie było na pewno z politycznych i po części społecznych powodów ważne, ale nie stanowiło przeciwwagi dla Rzeszy (wpływ Państwa Podziemnego na obywateli niezaangażowanych bezpośrednio w jego działanie był minimalny). A to oznacza, że odpowiedzialności za czyny - zarówno dobre, jak i złe - Polaków z okresu II wojny światowej nie da się zepchnąć na żaden byt państwowy, nie da się jej oddalić przez przypisanie jej nie społeczeństwu rozumianemu jako zbiór jednostek, lecz abstrakcyjnej strukturze państwowej.

To zaś zasadniczo zmienia odczuwanie wstydu i dumy. Duma za czyny nielicznych łatwo staje się w powszechnym odczuciu wspólna, narodowa. Natomiast wstyd albo znika całkowicie, stając się co najwyżej indywidualnym odczuciem, albo - jeśli zaczyna funkcjonować w społecznej świadomości - staje się zdecydowanie dotkliwszy. Taki wstyd i taka duma zdecydowanie bardziej utrudniają i tak rozchwiany proces budowania tożsamości. Bo jeśli wstyd może prowadzić do narodowej dumy, to tylko dlatego, że jest odczuwany w ramach i w obrębie określonej tożsamości, nie podważa jej, ale ją wspiera przez uznanie wielowiekowej ciąłości. A jeśli ciągłość ta została zerwana, to sytuacja zasadniczo się komplikuje.

\section{IV}

Na zachodzące współcześnie procesy w obrębie kształtowania polskiej pamięci, zwłaszcza tej, która odnosi się do XX wieku, warto moim zdaniem spojrzeć właśnie jako na próbę rekonstrukcji tożsamości opierającej się na przynależności do określonego państwa bardziej nawet niż społeczeństwa czy narodowości. Stawką w tej grze jest obraz „Polski” jako tworu państwowego w tych momentach, w których o Polsce jako niepodległym kraju mówić nie 
sposób. Jest to więc próba takiego przepisania historii i pamięci o niej, by możliwe było zachowanie ciąłłości istnienia Polski, a co za tym idzie - przynależności do określonego kraju oraz zbiorowej tożsamości. Posługując się terminologią Ledera, jest to próba stworzenia spójnego 'my', mimo - a może zwłaszcza dlatego - że w pewnych momentach nie było wcale jasne, kim 'my' jesteśmy i czy jest jakieś 'my'.

Budowanie określonej wspólnoty, owego nadrzędnego 'my', które w dodatku może legitymizować się przynależnością do konkretnego państwa, odbywa się obecnie za pomocą dość prostego mechanizmu, o którym już częściowo wspominałam na początku tego artykułu. Jest nim uporczywe powtarzanie, powracanie do wydarzeń, wobec których łatwo przyjąć jednoznaczne stanowisko. Jak się nietrudno domyślić, owa jednoznaczność wiąże się z jednej strony z koniecznością jasnego, dobitnego zaznaczenia różnicy między 'my' a 'oni', z drugiej zaś - z równie silną - potrzebą dumy, z tego, co akurat 'my' zrobiliśmy. Z tego powodu najważniejszą rolę w pamięci o II wojnie światowej odgrywają wydarzenia, w których 'my' jesteśmy elementem sprawczym i które - co moim zdaniem równie ważne - da się powiązać z funkcjonowaniem mechanizmów państwowych.

Rosnąca popularność powstania warszawskiego jako szczególnie istotnego wydarzenia dla budowania polskiej pamięci wynika bezpośrednio właśnie z tych dwóch czynników. Było to jedno z nielicznych wydarzeń z okresu II wojny światowej, w którym to 'my' byliśmy sprawczy, to 'my' podjęliśmy decyzję. Choć w ocenach tej decyzji - nie wspominając już o jej skutkach - można się różnić, powstanie jest szczególnym punktem pamięci, w którym łączy się fantazja o sprawczości i aktywności społeczeństwa polskiego z iluzją funkcjonowania państwa polskiego w czasie okupacji. Powstanie to jest przecież współcześnie odczytywane jako akt zbrojny o charakterze wojskowym, a więc państwowym właśnie, oraz - równocześnie - ucieleśnienie społecznego, oddolnego dążenia do działania, do przeciwstawienia się uciskowi.

Podobny charakter - choć na mniejszą skalę - ma pamięć o żołnierzach wyklętych, mocno ostatnio obecna w publicznym dyskursie. Już samo określenie 'żołnierz wyklęty’ wskazuje na pewien skrzętnie ukrywany paradoks pamięci.Żołnierz to zawsze członek armii określonego państwa, to część sił zbrojnych, nie zaś - jak jest w tym przypadku - partyzant, ktoś, kto występuje przeciwko władzy państwowej. Fakt, że mówimy dzisiaj właśnie o żołnierzach wyklętych, a nie np. o członkach antykomunistycznej partyzantki, jest wyjątkowo wymowny. Zgodnie z logiką tego określenia powojenne 
podziemie - niewspierane przecież, przynajmniej oficjalnie, przez rząd na uchodźstwie - było w większym stopniu 'państwem' niż komunistyczna Polska. Budowanie mitu żołnierzy wyklętych, tak jak i powstania warszawskiego, służy więc wyraźnie konstruowaniu mocnego, łatwego do uchwycenia i sprawczego polskiego 'my', które zachowuje ciągłość mimo zmian politycznych.

Taki sposób konstruowania tożsamości i pamięci zbiorowej ma jednak bardzo wyraźne wady. Najważniejszą jest bez wątpienia jego skrajna wybiórczość. Historia społeczeństw, które, posługując się częściowo terminologią Andrzeja Ledera, określiłabym nie tyle jako słabe, co jako niestabilne, nie składa się przecież w głównej mierze z aktów siły, dominacji czy nawet sprawczości. Więcej w niej rezygnacji i prób radzenia z dominacją, więcej też różnych reakcji na podległość, przez co skala relacji z 'innym' jest też zdecydowanie bardziej skomplikowana. Niewiele z niej jednak pozostaje, gdy pamięć o przeszłości przykrawa się do z góry wymyślonego wzorca.

Selektywność takiej pamięci skutkuje więc z jednej strony wyłączaniem z jej zakresu wszystkiego, co do modelu sprawczego i aktywnego polskiego ‘my' nie pasuje, z drugiej zaś - upartym powtarzaniem tych samych schematów pojęciowych, wracaniem do pewnych klisz i kalek, dzięki którym można zapełnić pamięć ogołoconą z nieakceptowanych wspomnień. Nawet wprowadzenie kolejnych wspomnień bardzo często opiera się nie na uzupełnianiu wyrw i luk, nie na komplikowaniu zbyt uproszczonych wersji pamięci, lecz zastępowaniu jednej kliszy inną, zbudowaną w podobny sposób. Mechanizm ten sprawia, że nawet jeśli do zbiorowej świadomości trafia wydarzenie, które było wcześniej nieobecne w publicznym dyskursie, jest ono szybko podporządkowane istniejącym już kliszom pamięciowym. Dzieje się tak np. z pamięcią o rzezi wołyńskiej, która szybko została włączona w dość prostą narrację o kolejnych krzywdach narodu polskiego, zamiast stać się podstawą do głębszego przemyślenia problemów tożsamości narodowej i konfliktów wynikających z bardzo źle pojętego nacjonalizmu.

Budowana w ten sposób pamięć zbiorowa i oparta na niej tożsamość jest - mimo dążenia do skrajnego ujenolicenia - niezwykle krucha. Wąski, rygorystyczny wzorzec pamięci wymusza traktowanie wszystkiego, co poza niego wykracza, jako zagrażające dla chwiejnego porządku. W takiej wizji historii każde nowe wydarzenie, które nie mieści się w istniejącej już kliszy pamięciowej, może zmusić do przebudowy całej, wciąż niestabilnej, tożsamości społecznej i narodowej, jest dla niej nawet nie wyzwaniem, ale 
po prostu zagrożeniem. Ten rodzaj pamięci jest przeciwieństwem pamięci dialogicznej lub wielokierunkowej, to specyficzna pamięć paradygmatyczna, w której wokół określonego wydarzenia i jego interpretacji buduje się tożsamość, podporządkowując jej wizję przeszłości, a nie pamięć, która jest splotem różnych wydarzeń oraz może dostarczać różnych wzorców tożsamości. Dlatego też reakcja polskiej pamięci zbiorowej na inne niż paradygmatyczna wersje pamięci jest tak nerwowa: np. pamięć Holokaustu nie jest traktowana jako pamięć równoległa albo pamięć, która uzupełnia oczywiste luki w preferowanych przez lata PRL-u trybach pamiętania o wojnie, lecz jako pamięć przeciwstawna, która zastępuje wersję pamięci o II wojnie jako o wydarzeniu destrukcyjnym dla polskiej narodowości i państwowości wersja pamięci, która w mniejszym lub większym stopniu obciąża polskie społeczeństwo niechcianym i niezrozumianym wstydem.

Jedynym sposobem na przełamanie tego specyficznego impasu, w którym pamięć zbiorowa i indywidualna staje się zakładnikiem potrzeby wytworzenia spójnej tożsamości, jest akceptacja faktu, że różnorodność pamięci i jej wielokierunkowość nie musi oznaczać chaosu ani rozchwiania, a odmienne wersje pamięci nie zawsze muszą być sobie przeciwstawne. To jednak - paradoksalnie - wymaga pracy nie tyle nad przeszłością i pamięcią o niej, lecz nad teraźniejszością i przyszłością, które powinny stać się wyraźniejszym niż przeszłość punktem odniesienia dla budowania wspólnej tożsamości. 


\section{Abstract}

\section{Justyna Tabaszewska}

THE INSTITUTE OF LITERARY RESEARCH OF THE POLISH ACADEMY OF SCIENCES (WARSAW)

Cliches and Overexposures: Gaps and Surplusses of Polish Memory

Tabaszewska examines two key issues in the functioning of Polish memory, namely forgetting and contemplation. They can be seen as two aspects of the same process of standardizing memory, of constructing memory in a way that is supposed to turn it into a comfortable tool in the construction of a given collective identity. Forgetting and contemplation can therefore be read as a memory loop of sorts, rooted in the need to reconstruct an identity based on belonging to a given state. The selective and stereotypical aspects of collective memory largely result from attempts to produce an image of the past that would legitimize a sense of belonging to a stable state organism looking back on hundreds of years of continuity.

\section{Keywords}

collective memory, cultural memory, affect, forgetting, shame, pride 